\title{
Refugees, Identity, and the Limits to Inclusion: Revisiting Landlord-Stranger Reciprocity Relations in Contemporary Liberia
}

\author{
Maarten Bedert 우
}

\begin{abstract}
Refugees in sub-Saharan Africa residing among host communities experience the need to articulate belonging in order to generate a greater sense of security. Based on the individual life stories of Ivorian refugees in Northeastern Liberia in 2011, Bedert finds that local patterns of integration between landlords and strangers are foregone by the bureaucratic identity of refugees as imposed by the international community. In addition, local integration is not self-evident, as it entails a degree of reciprocity and mutual recognition. In the eyes of landlords, strangers are evaluated based on what they can bring to the table.
\end{abstract}

Résumé: Les réfugiés d'Afrique subsaharienne résidant au sein des communautés d'accueil éprouvent le besoin d'articuler leur appartenance afin de générer un plus grand sentiment de sécurité. Sur la base des récits de vie individuelles de réfugiés ivoiriens dans le nord-est du Libéria en 2011, Bedert constate que les modèles locaux d'intégration entre propriétaires et étrangers sont abandonnés par l'identité

African Studies Review, Volume 63, Number 3 (September 2020), pp. 640-659

Maarten Bedert is an independent scholar who holds a PhD in social anthropology from the Martin Luther University Halle-Wittenberg. He previously studied African Studies at the University of Ghent and Leiden. This research was conducted as part of the research group "Integration and Conflict along the Upper Guinea Coast" at the Max Planck Institute for Social Anthropology in Halle. Bedert's research interests include the experience of social change and innovation, imagination, secrecy, religious change, migration, social conflicts, and HIV. E-mail: bedert.maarten@gmail.com

(C) The Author(s), 2020. Published by Cambridge University Press on behalf of the African Studies Association. This is an Open Access article, distributed under the terms of the Creative Commons Attribution licence (http:/ / creativecommons.org/ licenses/by/4.0/), which permits unrestricted re-use, distribution, and reproduction in any medium, provided the original work is properly cited.

doi:10.1017/asr.2020.51 
bureaucratique des réfugiés imposée par la communauté internationale. De plus, l'intégration locale n'est pas évidente, car elle implique un certain niveau de réciprocité et de reconnaissance mutuelle. Aux yeux des propriétaires, les étrangers sont évalués en fonction de ce qu'ils peuvent apporter à la table.

Resumo: Os refugiados da África subsaariana que residem em comunidades de acolhimento experienciam a necessidade de gerir a sua integração e pertença, de modo a criarem um maior sentimento de segurança. Com base nas histórias de vida pessoais de refugiados da Costa do Marfim no nordeste da Libéria em 2011, Bedert conclui que os padrões locais de integração entre os proprietários rurais e os estrangeiros são predeterminados pela identidade burocrática dos refugiados nos termos em que esta é imposta pela comunidade internacional. Além disso, a integração local não é um dado adquirido, uma vez que implica um determinado grau de reciprocidade e reconhecimento mútuo. Aos olhos dos proprietários rurais, os estrangeiros são avaliados com base naquilo que têm para oferecer.

Key Words: Liberia; integration; refugees; identity; reciprocity

(Received 21 March 2019 - Revised 6 April 2020 - Accepted 10 April 2020)

\section{Introduction}

I encountered Joseph, a young Ivoirian refugee who had lived among a local host community for several years, on a difficult day. He was contemplating whether he should stay in Karnplay or whether he should move to Monrovia, Liberia's capital. As the owner of a successful computer shop, he also operated a charging booth where people could bring their phones to be charged. One of his customers lost the ticket identifying his phone, and somebody else had come to collect it. The phone's owner accused Joseph of theft and threatened to take him to the police station. Joseph complained: "This city is some kind of way; people are quick to make something out of nothing. I came here as a stranger, and since I am doing well it creates so much jealousy." Joseph had built quite a reputation. The newly elected MP was a big customer during the campaign, and following his victory he came into the shop, bought two new printers, and told Joseph, "Tell me what you want, and I will give it to you." Still, at times Joseph felt as if life was impossibly difficult, as he remained only a stranger, and that required humility on his part.

Joseph's story is illustrative of tensions between landlords and stranger refugees in sites of displacement across sub-Saharan Africa. Landlordstranger relationships are an important axis of integration for Ivorian refugees who relocated to Liberia between 2011 and 2013. A focus on the individual refugee strategies highlights the significance of local approaches to integrating "others" as compared to the national and international programs that claim to protect vulnerable refugee populations. Local relations between landlords and strangers are distorted due to the official protocols that set refugees apart from their host communities. The label of "refugee" 
(see Zetter 1991), in particular, prevents Ivorians living outside of the refugee camps in Liberia from being fully accepted as "strangers" by their local Liberian hosts. I describe how refugees themselves confront and deal with this difficult disjuncture of protocols.

The discipline of refugee studies has emphasized the discursive power of the bureaucratic identity label "refugee," which, as a normative legal category, is able to simplify and transform complex identities (Zetter 1991). Liisa Malkki (1995:507-9) has described how a functionalist reasoning shapes "the refugee," portraying persons so labeled as "out of place" in their host countries, with the implicit assumption that their place of origin is their only "natural" place. Stephen Lubkemann (2008:188) highlights the way displaced people are framed by a "multifaceted package of losses." This attitude, often adopted by humanitarian agencies, carries the implicit, and simplistic, assumption that refugees were living in a harmonious world before the eruption of whatever crisis uprooted them. This study counters such assumptions by demonstrating the diversity of refugee histories and experiences and the way these evade representational norms. By focusing on refuge as a process rather than a state of being, it is possible to understand how the refugees' webs of social relations are constructed and reproduced in different environments (Shadle 2018; Englund 2002). The simplistic notion of "African Hospitality" toward refugees is displaced, here by the intricate local processes of social integration and their consequent precarity.

Migration, forced or otherwise, has long been a defining feature of social life along West Africa's windward coast (d'Azevedo 1962). Well before the emergence of nation-states (Horton 1971), local communities developed ways to integrate people into their own communities, using the institutionalization of relations between landlords and strangers. These methods of integration have had both social and political consequences. Landlords derive political and ritual authority from being the autochthonous original settlers in a territory, and they expect strangers to show loyalty and respect to their hosts in return for protection and security (Højbjerg 1999). Landlordstranger relations are used to describe contacts between autochthonous populations and European traders (Brooks 1993; Rodney 1980), but they are also the guiding principles for interaction between local groups (Mouser 1975). Vernon Dorjahn and Christopher Fyfe conclude that in the case of the changing relations between landlords and strangers among the Temne of Sierra Leone, the key relations are "on a person-to-person basis." Their interlocutors put forward "honesty" and "being well-mannered" as prerequisite qualities for being a good stranger. "Compatibility is important," they write, "since the tenant's household will become, in some cases, virtually a part of his landlord's" (1962:392, emphasis added).

The political crises affecting Liberia and its neighbors since the 1990s have produced a massive influx of newcomers into Liberia, forcing relations between landlords and strangers into a new light. In this context, there is a narrow line between the potential for integration of newcomers and the threat of renewed tensions between newcomers and the host community, especially when the hosts perceive disrespect to customary relations by the 
newcomer population (Fairhead 2010; Højbjerg 2010; McGovern 2012; Ménard 2017). Ingunn Bjørkhaug and co-authors (2017), for instance, have demonstrated how host-stranger relations ("the stranger-father institution") do not guarantee the long-term integration of Ivoirian refugees in Liberia; local hospitality, these authors conclude, is limited in time.

I use personal narratives of Ivoirians who settled in Liberia to deconstruct categories of "refugee" and "stranger." I explore how personality traits and the experiences of individual actors shape interpersonal relations and facilitate or prevent local integration in light of international interventions. Neither local institutions nor labels imposed through international interventions are monolithic or static, but both are infused with meaning through interaction, always keeping in mind the power relations between different social pathways toward conviviality.

First, I provide a brief overview of the refugee crisis in northern Nimba County following the Ivorian presidential elections. I then describe a UNHCR verification exercise through which the politics behind the label of "refugees" are revealed. Third, I elaborate on the more complex experiences of Tarkpor and Joseph, while also presenting a brief genealogy of landlord-stranger reciprocity relations.

\section{Understanding the Refugee Experience Based on Personal Narratives}

In order to explore the recent dynamics surrounding landlord-stranger relations, I draw on observations made during the arrival of refugees from Ivory Coast in the north of Nimba County during 2011. Data presented here were collected as part of a larger project dealing with changes in landlordstranger reciprocity relations and local dynamics of secrecy in the aftermath of the Liberian civil war (1989 to 2003) (Bedert 2016). This research focused on the way landlord-stranger relations are invoked to (a) articulate social distinction (Bedert 2018), (b) interpret relations between the Mandingo and Dan ethnic groups (Bedert 2017a), and (c) claim local positions of power by drawing on local settlement histories (Bedert 2017b). The present analysis draws on arguments laid out in this previous work.

Between August 2011 and August 2013, I was based in Karnplay, a small town with over 7,000 inhabitants close to the Ivorian border. During the 2011-2012 electoral crisis in Ivory Coast, Ivorians crossed the border and either settled among local communities or moved into camps managed by the UNHCR. The ethnographic data presented here draw on the experiences of refugees who settled among these local communities.

In this discussion of the strategies employed by refugees to facilitate their integration, I particularly rely on the experiences of two Dan individuals, Tarkpor and Joseph (both pseudonyms). The Dan are a small ethnic group living on both sides of the Liberian-Ivoirian border, to which most refugees in northern Nimba county belong. Tarkpor was the former chairman of the refugee organization in the district. In a one-time in-depth interview which was audio-recorded at his residence, we discussed what he had experienced 
in his official capacity and also his personal trajectory as a refugee in Liberia. I got to know Joseph over a longer period. Much of what I describe is based on informal observations at his shop and of his interactions with others. These observations were followed up by a formal audio-recorded, in-depth interview which focused on, but was not restricted to, his experiences as a refugee. I present both narratives, as they represent two divergent experiences that illustrate the tension between local dynamics of integration and the politics of official national and international programs.

The data were collected using the extended case-method (Burawoy 1998). Both narratives are set against broader observations as part of my research related to landlord-stranger dynamics. Throughout my stay, I followed the circulation of rumors and informal discussions dealing with the presence of the refugees. I conducted interviews with the city mayor, with officials of the national and international organizations dealing with the refugee situation (i.e., Liberia Refugee Repatriation and Resettlement Commission [LRRRC] and UNHCR) and with other refugees. Tarkpor and Joseph's experiences as refugees are complemented here with descriptions of their everyday practices, which allows a richer picture of the complexity of their actions. The complexity of these individual experiences deconstructs the relationship between the individual and society and stands in stark contrast to the functionalist and reductionist practices assumed in national and international policies (Caplan 1999).

\section{The Ivorian Crisis and Refugees in Northeastern Liberia}

It was the presidential election of 2010 in Ivory Coast that led to the 2011 refugee crisis. Although the country's Independent Electoral Commission had proclaimed opposition candidate Allassane Ouattara the winner, the Constitutional Council gave the victory to the incumbent Laurent Gbagbo. In the midst of the ensuing political confusion, national and international protests erupted. This was the latest episode in a political crisis that had been going on since president Félix Houphouët-Boigny died in 1993 without a successor. From that year onward, there had been growing animosity between people from the south and from the north; those from the south claimed autochthony and denied the citizenship status of people from the north. In 2002, this led to the de facto partition of the country between the north, which was controlled by rebel groups, and the south, which was still held by the government and its troops. ${ }^{1}$ Civil war ensued (Bah 2010:604).

Peace led to new presidential elections, which in turn led to the violent post-electoral crisis of 2010 (Straus 2011). As a result of that crisis, about 200,000 Ivorians crossed the border into Liberia. For many of them, their stay was relatively short; the UNHCR reported that 135,000 were able to return home within the same year (UNHCR 2012). As the refugees entered Liberia in 2011 and 2012, national authorities and international agencies were caught unprepared, and refugee camps were not constructed until several months after the first people crossed the border (Hartman \& Morse 2018). By 
the end of 2011, the UNHCR (2012) reported that roughly 30,000 people were still residing in refugee camps in Liberia. In contrast, over 80,000 were residing in private accommodations in Nimba and Grand Gedeh counties. Many opted for private accommodations as they preferred to stay out of the camps so as to retain a sense of freedom. Refugees who entered Liberia were encouraged to avoid the communities immediately adjacent to the border, and to instead move on to some of the larger urban centers. When they entered the country, they were officially registered and given aid benefits such as bags of rice, buckets, and blankets.

Most of the refugees in Liberia were Guere and Yacouba individuals who feared retribution for their political choices (Bjørkhaug et al. 2017). Most people who settled in and around Karnplay were Yacouba (see Figure 1). As a group, the Yacouba have strong connections with communities on the Liberian side. They are the same ethnic group going by different names; they speak the same language and refer to themselves as Dan speakers. In English, they are referred to as Gio, while Yacouba is the ethnonym used in French (Holsoe \& Lauer 1976). For the sake of simplicity, I employ the ethnonym Dan throughout.

Despite the physical border dividing the Dan, there has long been a high degree of inter-marriage, trade, and cross-border mobility between the two groups. Along the border, there are numerous government immigration checkpoints, but also many "bypasses," which are non-monitored crossing

\section{Figure 1. Map of the Region. Courtesy of cartographer Jutta Turner (Max Planck Institute for Social anthropology)}

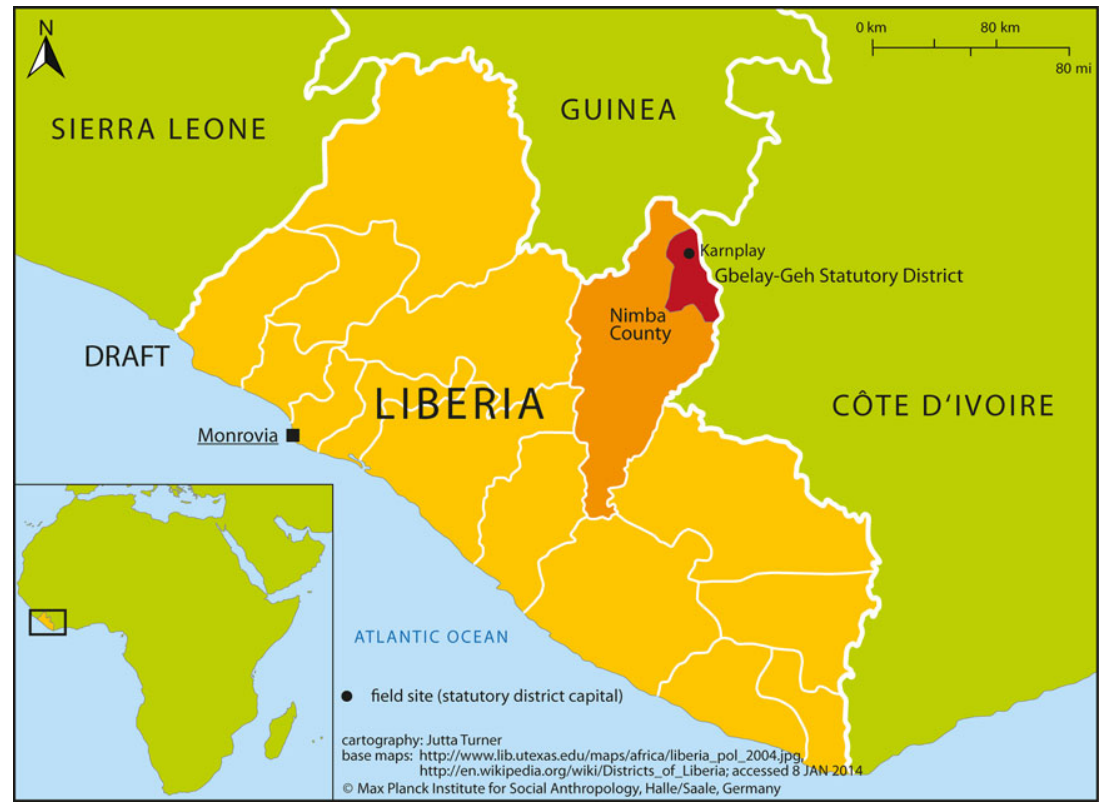


points. Goods, such as agricultural produce, are brought across to the side where farmers can get the best price. Many people buy goods from local markets on one side of the border and cross to sell them on the other side without documentation or registration. Liisa Malkki has lamented the way the asylum country for refugees is often "rendered as unfamiliar as if it was worlds apart" (1995:508). This broader background serves as an indication that many people, at least in this case, are familiar with life across the border in manifold ways. This is an issue that impacted upon both Tarkpor and Joseph, as I show in my account of their experiences that follows. In 2011, however, the physical border became a pertinent issue when refugees crossed it in large numbers. ${ }^{2}$ Formal actions to secure the border were highly dependent on rumors. With the outbreak of violence in Ivory Coast, unrest returned to Liberia also. It was rumored that many Liberian ex-combatants had gone to Ivory Coast in search of opportunities as militia fighters, leading to fears that the Ivoirian conflict would spill over into Liberia. At the same time, the planned withdrawal of the United Nations Mission in Liberia (UNMIL) had meant that the UN security forces that had been stationed along the border were now gone. As a result, the border was officially closed during much of this period. This did not, however, prevent people from moving in either direction.

\section{The National Order of Things: a UNHCR Verification Exercise}

Refugees are considered to be vulnerable populations that require help and assistance. As a result, the diversity of experiences that people moving across borders go through is reduced, in order to reflect their status as victims. This is a position adopted by the Liberia Refugee Repatriation and Resettlement Commission (LRRRC), which is the main implementing agency in Liberia and a close collaborator with the UNHCR. Labeling people who cross the border as refugees has significant implications for their potential local integration. Roger Zetter has pointed out that invoking the label of refugee not only forms identities but also actively transforms those who are labeled. He argues that the process of labeling is as significant as the label itself (Zetter 1991:44-45). It involves the stereotyping of individuals, something which implies a reduction of people's identities to singular clear-cut categories; people become client groups with specific needs. Implementing the label of refugee also makes relations of power and levels of control visible. People need to conform to the categories and the stereotypes associated with their identities. The label of refugee becomes a tool through which loyalty and conformity is enforced. The label is also non-participatory; it does not involve any input from the people affected.

From the perspective of refugee agencies and implementing partners, this reductionist tendency might be viewed as a necessity in order to protect vulnerable populations. Refugee agencies are frequently confronted with non-refugees who are trying to secure refugee benefits. These are practices that are recognized by aid organizations in various parts of the world (Kibreab 
2004). To help maintain accurate identifications, the UNHCR set up a verification exercise. They decided to scale down aid to refugees living outside of the camps in 2012, so they put in place a system to help them keep track of those who were genuine refugees. The following narrative demonstrates how the labeling of refugees leads to the formation of a distant and essentialized Other in a diverse and dynamic border region.

In their statistical yearbook, UNHCR (2012) reflects on the biometrical verification exercise it conducted in Liberia. Here, they collected fingerprints and verified the identities of the Ivorian refugees. The intention behind this exercise was not only to better track the movement of refugees but also to root out Liberians who were diverting to themselves benefits intended for refugees. These corporeal indexes align the status of refugees not only with a legal and social frame of reference but also with a biological one. The UNHCR warned that registering as a refugee in this biometric system could have severe consequences for people's claims to Liberian citizenship (UNHCR 2012:19). A side effect of this powerful discursive message was the disregard for local mechanisms of integration and the complexity of linguistic and kin relations that characterized the existing cross-border networks.

On one afternoon in mid-May of 2011, UNHCR tents were erected next to a deserted school campus in Karnplay. Their set-up was imposing: by the evening, a contingent of jeeps and trucks had arrived, a generator had been set up to provide electricity, and the armed Emergency Response Unit (ERU) of the Liberian police was already providing security. The next morning, a UNHCR officer explained that they would be collecting fingerprints in order to reduce fraud and stealing. He stated that providing for refugees was very expensive, implying that people who were on the program undeservedly spoiled it for everybody else. He wanted to kick out those who cheated. As a former spokesperson for the refugee community later mentioned, the number of refugees living in the area was reduced from 1298 to 472. As part of the verification process, refugees were encouraged to move to the camps, where they would continue receiving support and protection. For those who stayed out in the communities, material support would cease within a few months.

As the exercise commenced, refugees waited in line under the hot sun. Soon, rumors started to circulate about the firm line of investigation put forward in this exercise. One by one, families were allowed inside. When fraud was suspected in the first verification step, a blue dollar sign was drawn on their file and people were pulled aside for questioning. They were sent to the "interrogation room" where they were further questioned by two junior lawyers and one senior lawyer (all of whom were employees of the UNHCR). I was allowed in the room to observe a few cases. One criterion by which people's eligibility was judged was language. One of the first people who came in was dismissed because she spoke almost no French, and when she pronounced the name of one of the Liberian towns, she said Larpeah One (in English) where the interrogators would have expected her to say une. 
When she discussed the name of a month, she said January and not Janvier, which the panel also interpreted to be a sign of her cheating. This overlooks the pertinent fact that multilingualism is often standard in the region (Lüpke 2010). Being linguistically familiar with the host country, in other words, disqualified her from being a "true" Ivorian, thereby negating her claim to refugee status. In a similar case, another family was disqualified because the children spoke some Dan while their mother only spoke Dyula. As she didn't speak French or English, her interrogators claimed, they would not be able to communicate with one another. A second criterion is autochthony, being born from the soil, which was observed when a man came in and explained that he didn't "want to lie"; both he and his parents had been born in Guinea. When he was still very young his whole family had moved to Ivory Coast, and he had no memory of Guinea whatsoever. The council decided that he was Guinean, and not Ivorian. When questioned, he claimed to be an Ivorian citizen, but as he could not produce any valid documents, his claim was dismissed. The UNHCR officer told me he had known from the beginning that the man was Guinean because he held his portable radio in a specific way. "This is something you cannot lose, even if you live somewhere else for 1000 years," he claimed. The man's identity was reduced to citizenship by birth, and to mannerisms which were presumed to be innate.

The comments by UNHCR officials indicated that they had a very specific view of what qualifies one as "true Ivorian" and therefore as a potential refugee. A clear-cut line was maintained between those who conformed and those who did not (or could not). In addition to the observations of individuals, much reliance was placed on official documents. Everybody was asked to produce some form of documentation that demonstrated that they were Ivorian citizens. One lady came and presented a leaflet about childcare in French that she had received after having giving birth. She was ridiculed and dismissed, as this did not "prove anything." Complaints from others stating that many people never owned passports or ID cards were also dismissed. Whether the investigators intended it or not, a bureaucratic reality was being imposed on people's experience throughout this exercise. Linguistic markers were utilized in a functionalist, reductionist, and essentializing way in order to demonstrate national citizenship. The idea of an investigative council to decide the validity of the claims shows that the label of refugee is wielded with a lot of legitimacy. In Liisa Malkki's (1995) terms, refugees are treated as being "out of place."

People residing in the camps reported preferences for staying among their own kin (Bjørkhaug et al. 2017), whereas those who decided to live among the communities expressed a desire for more freedom and for opportunities to create a life for themselves. The technologies of control that are characteristic of refugee camps (Malkki 1995:498) were, in this case, being reproduced outside the borders of the camp also. This group is not literally confined in camps, but its members are singled out and treated as if they live in an invisible camp, distinct from the local community they wanted to live with; this occurred under the pretended rubric of security and safety. 
As a result, the effective operation of local mechanisms of integration became impossible. For those affected, it became a trade-off; acceptance of the label "refugee" provided access to materials and financial benefits provided by the international community, while also distancing them from local populations.

Contrary to the singular and reductive identities imposed by the label of "refugees," two narratives illustrate the complexity of experiences and identities of people who crossed into Liberia. Tarkpor and Joseph represent two divergent trajectories followed by refugees in their quest for security and belonging. Before presenting these narratives, I elaborate on the nature of the landlord-stranger relations in West Africa, and the way these facilitate the integration of newcomers into existing communities-or at least, how they could facilitate that integration, if they were allowed to operate.

\section{The Significance of Reciprocity in Landlord-Stranger Relations}

Landlord-stranger relations are not historical relics. Anthropologists have described how they continue to structure contemporary social hierarchies. ${ }^{3}$ Jacqueline Knörr and Wilson Trajano Filho (2010) identify landlord-stranger relations as one of the key local institutions through which social relations are reproduced along the Upper Guinea Coast and through which the past is brought into the present. William Murphy and Caroline Bledsoe (1987) identified two key elements around which landlord-stranger relations are articulated: kinship and territory. As the past is remembered, these authors argue, some events are given greater prominence than others in narratives of the past. These events become pivotal and gain significance and prominence as they are told and retold to justify the political or ritual authority of groups (see also Højbjerg 1999).

According to Mike McGovern (2012), landlord-stranger relationships should be viewed as an idiom that allows both the weak and the powerful to deal with insecurity. He has described how refugees can invoke real or imagined kin relations in order to articulate belonging in cases where they might at first be excluded from host communities (see also Højbjerg 1999, 2010). At the same time, landlord-stranger relations are invoked by powerful elites to claim autochthony and the right to citizenship, thereby excluding others. Since the end of the war in Liberia, both dynamics of integration and exclusion have been observed.

A key element that determines the relationship between landlords and strangers is often left under-conceptualized; the relationship between both groups entails a certain degree of reciprocity. Based on the narratives of both Tarkpor and Joseph, I demonstrate that reciprocity is the operative word in defining landlord-stranger relations. Whereas "landlord" and "stranger," as labels or categories, define or establish the order of the relationship between two groups or individuals, it does not define the quality of that relationship. In certain contexts, this dimension of social relations "works," but not in others; to understand this contrast, we need to consider the implications of 
reciprocity. The following description by Trajano Filho sums up this pattern of relationship well:

Landlord-stranger reciprocity was a mechanism developed by societies of the Upper Guinea coast to conceive, categorize and deal with otherness. What is unique in this cultural pattern of relating to others is that it does not work by establishing distinctive oppositions of us/them, according to which the other has its humanness symbolically withdrawn. Nor does it create fixed barriers separating the groups, whose relations are thus oriented by negative reciprocity. Rather, landlord-stranger reciprocity incorporates others as strangers in the landlord's communities in such a way as to allow them to become part of the rulers' corporate group of kin, clients and adherents while at the same time keeping them distinct. (2010:161-62)

When the label of refugees is imposed on people residing among local communities along the Liberian border, this prevents them from engaging fully in landlord-stranger relations. As refugees are legally and socially placed outside of their host communities, as seen in the verification exercise described above, they are unable to reciprocate in the ways prescribed by the idiomatic set of relations. This undermines their ability or opportunity to become incorporated into the local, ruling, group.

\section{Tarkpor: A Tale of Separation and Exclusion}

When I met Tarkpor, he was living in a temporary shelter erected by local implementing partners of the UNHCR. He had entered Liberia in November 2010 with a larger group of refugees who had all crossed the border at the same time. He spent two months in Loguatuo Old Town, a small settlement close to the border where he was living with a host family who provided him a place to stay. It was there that he was officially registered as a refugee and was given a refugee ID card and a ration card with which he would receive food regularly. Upon his registration, UNHCR officers advised him to move to a town further away from the border. They redirected him to a designated community that could accommodate refugees. He took their advice and resettled in one of the quarters in Karnplay. As there was little infrastructure in Karnplay to house refugees, he found a host family in one of the quarters on the outskirts of town. When he moved in, he entered what could have developed into a landlord-stranger relationship. Not long after he arrived there, though, he had a dispute with his hosts over some money that he had borrowed. He felt forced to leave this home and settle in another part of town. He was unable to respect the informal contract he had entered into with his landlords and he could not, therefore, maintain his role as "proper" stranger. He did not meet their generosity with the required respect. He found it necessary to leave and abandon thereby the precarious relationship he had built. 
Tarkpor found a new place, in a temporary shelter constructed especially for refugees. There, he was bored and found himself with nothing to do. He turned to a local LRRRC officer whom he had met after he crossed the border. He asked him what he could do for the refugee community living in Karnplay. The officer directed Tarkpor to the city mayor's compound, where refugees had regular meetings with city authorities. During one of those meetings, the mayor took the liberty of appointing Tarkpor as the chairman and spokesperson for the refugees. As his first act, Tarkpor drew up a list of all the refugees living nearby so that NGOs could provide the necessary goods and services to the right people. From then on, Tarkpor took it upon himself to go around the community and to mobilize refugees to attend meetings, to register for benefits, and to take advantage of the aid that was available to them from the international community. Soon, he claimed, he became the go-to person for all the local and international organizations dealing with the refugees.

Although he had failed to establish lasting connections as a stranger with his local hosts, Tarkpor succeeded in becoming a prominent figure in the context of the international intervention, in the relationships between those organizations and the refugees. He actively sought ways to withdraw from the local community, as this would liberate him from the reciprocity that was demanded from him as a "stranger." As a refugee, the responsibility for his security and well-being was shifted away from his local host community to the national and international aid infrastructure. Tarkpor managed to enjoy material and social benefits through his NGO contacts. However, as his responsibility and standing grew, so did the jealousy of other refugees toward him. There was a split among the refugees living in Karnplay, and accusations of embezzling food rations intended for refugees soon were made against him. He lost some of his credibility and his title as spokesperson. Tarkpor's social standing was taken away from him as suddenly and surprisingly as he had gained it.

Even though Tarkpor had moved to a new location and had managed to secure a solid network, the financial dispute with his former Karnplay hosts kept lingering on. The hosts had involved the police in order to try and recuperate the borrowed money. An investigation followed, and Tarkpor was convicted by the magistrate. He was brought to Sanniquellie, the county capital, and put in jail. By calling in a favor from one of his NGO connections, he subsequently managed to facilitate his release from jail. As there were continuing threats from his former host family, he was immediately brought to the refugee camp for his own protection. In the end, he spent three weeks in the camp.

Bitterness and disappointment could be heard in Tarkpor's voice as he narrated his experience of living with local hosts in Karnplay. At no point did he manage to settle and establish the sort of connections that would have allowed him a level of integration that could give him a comfortable life. As a refugee, his association with international NGOs offered him the security 
that, eventually, got him out of jail. It was this network that allowed him to physically escape the community he lived in and felt threatened by.

It was only when the refugee infrastructure was significantly scaled down and could no longer provide security that Tarkpor tried to re-establish some local relationships by invoking kinship ties: his goal this time was to try to secure a small portion of land. Only his in-laws, he claimed, were prepared to give him any help with this project. On top of that, his initial hosts repeatedly sent people to claim the debts he owed them, reminding him of the problems he had tried so hard to escape. Even in this later phase, Tarkpor found it extremely difficult to engage in the kind of relationships that were meaningful under the landlord-stranger idiom.

The behavior that Tarkpor exhibited meant that he did not comply with the "landlord-stranger reciprocity" deal. As a poor guest, he had borrowed money that he never repaid. As a result of his actions, his initial hosts brought their case against him to the police and the courts. Ordinarily, local associations and customary bonds require that informal mechanisms of justice rather than statutory courts should be invoked when disputes emerge. For instance, family elders are called upon to settle financial disputes. By calling the police, however, Tarkpor's hosts indicated that they did not trust him enough to settle the dispute in these customary ways. In contrast, as a refugee, the responsibility for his security was shifted from the local community to the international aid organizations, and thus followed those organizations' strict legal contours for defining refugee status.

As an indication of his inscription into the international legal discourse surrounding the position of refugees, Tarkpor went into his room during the interview and brought back a UN manual detailing the rights of refugees. He told me how he had studied this book so as to be able to negotiate with local organizations. Being labeled as a refugee had become the very basis of his economic and social life. Before participating in, and taking advantage of, the international intervention of the UNHCR, he had been in a state of precarity; after it was all taken away from him, he found himself, again, in a very precarious position.

\section{Joseph: A Familiar Stranger}

In contrast to Tarkpor's story, Joseph's experiences follow a different trajectory. His was a case where local integration and, potentially, assimilation, were actively sought. Even though he benefited from the intervention initially, he later actively rejected classification as a refugee and articulated his desire to be incorporated into the society of his hosts and landlords. He managed to adopt the role of stranger by citing kinship ties with some distant Liberian relatives.

When I first met Joseph in 2011, he was residing in Karnplay. He had set up a small computer and printing shop that he ran out of a rented warehouse. He helped people out by preparing documents and making photocopies, all for the right price. 
Joseph had crossed into Liberia in the beginning of April 2005, long before the crisis of 2010-2011. He journeyed on to Sanniquellie, the capital of Nimba county. In 2005, Liberia held its first presidential elections since the end of its civil war (1989-2003). As he witnessed the intense electoral campaigns of that year, Joseph began to fear renewed violence, and so reported himself to the offices of the International Red Cross. Officers of that agency then brought him to a refugee camp in Saclepea which had originally been set up to accommodate refugees fleeing the violence that followed the 2002 coup in Ivory Coast. His wife came tojoin him three months later. He officially remained in the camp until 2012, but while he was there, he attended a computer school in Monrovia between 2007 and 2009. His wife and son were with him in the camp, but when he could not stand being secluded from the rest of the world, he occasionally "escaped" for longer periods of time. If, at any time, residents needed to be physically present in the camp, friends would inform him of the new situation, and he would go back.

After finishing his education in Monrovia, one of his former teachers sold Joseph some used computers, which he took with him to Karnplay in 2009, choosing that city because it was an area with no computers. He took the opportunity to teach computer classes at a local high school and to open a shop providing computer services to local people.

The main reason he did not go back to the Ivory Coast was the death of his father, who was "killed by the rebels." His father was a strong partisan of the Front Populaire Ivoirien (FPI), the party of Laurent Gbagbo. Since 1996, Joseph had been a member of the Fédération estudiantine et scolaire de Côte d'Ivoire (FESCI), an organization closely linked to Gbagbo (Arnaut 2005, 2012). Joseph considered this a student organization and, since he was a student, he felt that he needed to be a member. However, as he tells the story, when the rebels came, they targeted FESCI and FPI members.

Joseph feared that it would not be safe for him to return to Ivory Coast: "As long as the people who killed my father have guns, I will not go back." Instead, he planned to make a future for himself in Liberia. Even though he had previously graduated from high school in Ivory Coast, he re-enrolled in high school in Karnplay so as to graduate from the Liberian school system. If he wanted to continue his education in Liberia, he reasoned, it would be better to have a degree from a Liberian school. He also negotiated with a landlord in Karnplay to use a piece of land which he turned into a pepper garden, and he managed to rent both a house and his shop location.

Even though he was grateful for the initial NGO protection that he had received, Joseph was utterly tired of being labeled a refugee. He found the label to be difficult to get rid of: "People are labeled as refugees and living as refugees.” In 2012 he was briefly repatriated to Ivory Coast but returned to Liberia after a few days. Upon his return, he refused registration as a refugee, claiming that his status would be more secure as a Liberian citizen. He explicitly stated: "I don't want to become a refugee again." Instead, he was considering what would be required to become a valued member of society. It 
so happens that his grandparents from his mother's side came from a small town close to the border in Liberia. He stated: "I should go there and say, 'I am back, I want you people to provide a recommendation. I want you to say: I am your son." He even contemplated adopting a more English-sounding name for his future job and school applications.

In contrast to Tarkpor's experience, Joseph became well established within his new community. He had his role to play by teaching computer classes at the local high school and by providing an important service to the community. He had become a valued stranger and showed little interest in returning to Ivory Coast. He even managed to claim shared ancestry and kinship ties, a key feature of landlord-stranger relations, by going back to his grandparents' home. His position as a stranger became even clearer when, in the aftermath of the UNHCR validation exercise, Joseph was arrested for providing false registrations to people. Teachers, preachers, local authorities, and friends actively pleaded his case to get him released from jail.

The longer Joseph stayed in this relatively small and close-knit community, the more he felt as if every problem ended up at his doorstep. When he was implicated in the case of phone theft, he complained to me that this might not be the most suitable place for him after all, as detailed in the anecdote at the beginning of this text. Maybe he was becoming a big man too soon-instead of being a docile subordinate as might be expected from a stranger - and others felt threatened by his success. The credit he had built up proved, in the end, to be insufficient to guarantee a lasting relationship. When I went back to Karnplay in 2017, Joseph came riding by on a motorbike, heading for the Ivorian border. He was residing in a bigger city, he said, and still working on his computer business. He had changed his name to make it sound more English/Liberian. He still had connections in Karnplay, but none were strong enough to keep him there.

Joseph's narrative reveals both the potential for integration of strangers and their precarity in the context of refugee infrastructure. Joseph gave up the protection that was offered to him as part of the refugee infrastructure and handed his fate to the local community, where he hoped to build lasting connections. Seeing little opportunity to go back to Ivory Coast, he felt that the label of refugee would hamper his local integration. Joseph's narrative also highlights the complexity of local mechanisms of integration beyond the simplified idea of "African hospitality." In the eyes of the landlords, as long as he had something to offer to the local community, he had value that made it appropriate to welcome him as a "stranger." His initial attitude also demonstrated that he was a loyal stranger, one willing to enter himself into the local hierarchy between landlords and strangers. In line with McGovern's (2012) analysis, the relationships as they were articulated offered Joseph both security in a time of crisis and a tool he could use to create a safer place for himself. Still, when his status as a successful entrepreneur rose, local communities revised their stance, seeing their chance to put the blame on the "Ivorian immigrant/refugee." 
Joseph needed the protection and care of his new community, and that community needed what he had to offer, his computer skills. His ability to claim a landlord-stranger relationship determined his success in the search for security. The importance of reciprocity in landlord-stranger relations implies that mutual recognition of this institutionalized relation by both landlords and potential strangers is indispensable. In her discussion of accumulation in Equatorial Guinea, Jane Guyer (1993, 1995) has elaborated on the significance of community composition via big men's gathering of followers with a diverse base of skills and knowledge. She describes how, in the equatorial Guinean case, the knowledge and skills strangers bring is crucial to whether they are considered as strangers or not. This leads her to conclude that landlords and big men do not simply accumulate for the sake of having the larger group of followers. In line with this argument, I argue that many of the refugees, as reflected in the narrative of Tarkpor, have little to offer to the local community where they reside, and that they therefore find limits to the hospitality that is extended to them (Bjørkhaug et al. 2017).

\section{Conclusion}

The experiences of these two Dan refugees who crossed into Liberia during moments of personal and socio-political crisis highlight some of the strategies employed by refugees in order to gain a stronger sense of security in a place other than home. On the one hand, refugees can become part of a bureaucratic and institutionalized scheme introduced by the international community through the aid infrastructures it has sponsored in the region. On the other hand, refugees can draw upon local mechanisms that facilitate integration into a community of autochthonous people, including people who can become their landlords in a landlord-stranger relationship. Through that relationship, protection and security can be assured. These strategies of identification are mutually exclusive. The bureaucratic politics of interventions oriented toward refugees are reductive. The label of refugee, based as it is on stereotypes, singles out people who are considered out of place. Even if they reside among local communities along the border, they are repeatedly reminded that this is not a permanent place for them to settle, reminded, in other words, that they are out of place. If the relationship they have with their host communities, through language or kinship ties, is articulated in a convincing way, they lose their bureaucratic qualification as refugees, as refugees are catered to by the international community and its bureaucratic organizations and are, eventually, expected to move on or return home.

For people like Tarkpor, refugees need to conform to the rules imposed upon them in order to gain security and a livelihood. In contrast, the label of refugee appears to restrict access to local avenues of integration. Hospitality is an integral aspect of landlord-stranger relations that exists throughout the Upper Guinea Coast. The key here is to establish local connections with a host community to facilitate recognition and integration. This can be done either 
through claims based on local territorial affiliations or through the assertion of shared matrilateral kinship ties.

For others, like Joseph, the question of local integration is complicated by the institutionalized quality of relationships between landlords and strangers. Mutual recognition and reciprocity are elements that warrant potential integration, but individuals and groups (whether families, clans, or ethnic groups) do not automatically enter relations that can be characterized as landlord-stranger relations. Those are reserved for a particular kind of stranger, the one who can offer some material benefit to the community he or she joins rather than one who simply wanders through the land.

In order to fully grasp and understand the precarious situation that refugees find themselves in, it is not enough to explore the way international bureaucratic labels are reproduced or local idioms are discursively performed. Instead, it is necessary to dig deeper to understand how social relations are constituted, how different regimes of identification and classification are invoked, and how these regimes co-exist, cooperate, or compete with one another.

\section{Acknowledgments}

I thank Anaïs Ménard for her comments on earlier drafts of this text and David O'Kane for the language editing of the manuscript. I also gratefully acknowledge the efforts of the editor and the anonymous reviewers in helping me clarify my argument and the presentation of my data.

\section{References}

Arnaut, Karel. 2005. "Re-Generating the Nation: Youth, Revolution and the Politics of History in Côte d'Ivoire." In Vanguard or Vandals: Youth, Politics and Conflict in Africa, edited by Jon Abbink and Ineke van Kessel, 112-44. Leiden: Brill.

- 2012. "Social Mobility in Times of Crisis: Militant Youth and the Politics of Impersonation in Cote d'Ivoire (2002-2011)." MICROCON Research Working Paper, 58. Brighton: MICROCON.

Bah, Abu Bakarr. 2010. "Democracy and Civil War: Citizenship and Peacemaking in Côte d'Ivoire." African Affairs 109 (437): 597-615.

Beavogui, Facinet. 1991. "Contribution a l'histoire des Loma de la Guinee de la fin du XIXe siecle à 1945." PhD Diss. University of Paris VII.

Bedert, Maarten. 2016. "Of Strangers and Secrets: Continuity and change in the articulation of belonging in Contemporary Liberia." PhD Diss. Martin-Luther University of Halle-Wittenberg.

— 2017a. "The Complementarity of Divergent Historical Imaginations: Narratives of Mobility and Alterity in Contemporary Liberia." Social Identities 23 (4): $430-45$.

- 2017b. "Notes on Settlement Histories of Gbelay-Geh Statutory District, Nimba County, Liberia." Field Notes and Research Projects/Max Planck Institute for Social Anthropology, Department Integration and Conflict 17. Halle/Saale: Max Planck Institute for Social Anthropology. 
. 2018. "Indexing Alterity: the performance of language in processes of social differentiation in postwar Liberia." In Creolization and pidginization in contexts of postcolonial diversity, edited by Jacqueline Knörr and Wilson Trajano Filho, 25371. Leiden: Brill.

Bellman, Beryl. 1984. The Language of Secrecy: symbols and metaphors in Poro ritual. New Brunswick, New Jersey: Rutgers University Press.

Bjørkhaug, Ingunn, Morten Bøås, and Tewodros Kebede. 2017. "Displacement, Belonging, and Land Rights in Grand Gedeh, Liberia: Almost at Home Abroad?" African Studies Review 60 (03): 59-79.

Brooks, George. 1993. Landlords and strangers: ecology, society, and trade in Western Africa, 1000-1630. Boulder: Westview Press.

Burawoy, Michael. 1998. "The Extended Case Method." Sociological Theory 16 (1): 4-33.

Caplan, Pat. 1999. "Anthropology, History and Personal Narratives: Reflections on Writing “African Voices, African Lives.” Transactions of the Royal Historical Society 9: 283-90.

Das, Veena, and Deborah Poole, eds. 2004. Anthropology at the Margins of the State: Comparative Perspectives. School of American Research Advanced Seminar Series. Santa Fe: School of American Research Press.

d'Azevedo, Warren. 1959. "The setting of Gola society and culture: some theoretical implications of variation in time and space." Kroeber Anthropological Society Papers 21: 43-125.

- 1962. "Some Historical Problems in the Delineation of a Central West Atlantic Region.” Annals of New York Academy of Sciences 96: 512-38.

Dorjahn, Vernon R. 1960. "The changing political system of the Temne." Africa 30: 110-39.

Dorjahn, Vernon R., and Christopher Fyfe. 1962. "Landlords and Strangers: Change in Tenancy Relations in Sierra Leone." Journal of African History 3 (3): 391-97.

Englund, Harry. 2002. From War to Peace on the Mozambique-Malawi Borderland. Edinburgh: Edinburgh University Press.

Fairhead, James. 2010. "Kouankan and the Guinea-Liberia Border." In The Powerful Presence of the Past: Integration and Conflict along the Upper Guinea Coast, edited by Jacqueline Knörr and Wilson Trajano Filho, 75-99. Leiden: Brill.

Fulton, R. M. 1972. "The political structures and functions of Poro in Kpelle society." American Anthropologist 1A, 1218-33.

Guyer, Jane I. 1993. "Wealth in People and Self-Realization in Equatorial Africa." Man 28 (2): 243.

- 1995. "Introduction." The Journal of African History 36 (1): 83-90.

Hartman, Alexandra, and Benjamin Morse. 2018. "Violence, Empathy, and Altruism: Evidence from the Ivorian Refugee Crisis in Liberia." British Journal of Political Science 50 (2): 731-55.

Højbjerg, Christian. 1999. "Loma Political Culture: A Phenomenology of Structural Form." Africa 69 (4): 535-54.

- 2010. "Victims and Heroes: Manding Historical Imagination in a Conflictridden Border Region (Liberia-Guinea)." In The Powerful Presence of the Past: Integration and Conflict along the Upper Guinea Coast, edited by Jacqueline Knörr and Wilson Trajano Filho, 273-93. Leiden: Brill.

Holsoe, Svend E., and Joseph J. Lauer. 1976. "Who Are the Kran/Guere and the Gio/Yacouba? Ethnic Identifications along the Liberia-Ivory Coast Border." African Studies Review 19 (1): 139-49. 
Horton, Robin. 1971. "Stateless Societies in the history of West Africa." In History of West Africa, edited by Jacob Ajayi and Michael Crowder, 87-128. New York: Colombia University Press.

Kibreab, Gaim. 2004. "Pulling the Wool over the Eyes of the Strangers." Journal of Refugee Studies 17 (1): 1-26.

Knörr, Jacqueline, and Wilson Trajano Filho, eds. 2010. The Powerful Presence of the Past: Integration and Conflict along the Upper Guinea Coast. Leiden: Brill.

Little, Kenneth. 1965. "The political functions of the Poro' I.” Africa 35: 349-65.

- 1966. "The political functions of the Poro' II." Africa 36: 62-72.

Lubkemann, Stephen. 2008. Culture in Chaos: An Anthropology of the Social Condition in War. Chicago: University of Chicago Press.

Lüpke, Friederike. 2010. "Multilingualism and Language Contact in West Africa: Towards a Holistic Perspective.” Journal of Language Contact THEMA (3): 1-12.

Malkki, Liisa. 1995. "Refugees and Exile: From 'Refugee Studies' to the National Order of Things." Annual Review of Anthropology 2: 495-523.

Marshall-Fratani, Ruth. 2006. "The War of 'Who is Who': Autochthony, Nationalism and Citizenship in the Ivoirian Crisis." African Studies Review 49 (2): 9-44.

McGovern, Mike. 2011. Making War in Ivory Coast. Chicago: University of Chicago Press.

— 2012. "Life during Wartime: Aspirational Kinship and the Management of Insecurity." Journal of the Royal Anthropological Institute 18 (4): 735-52.

Ménard, Anaïs. 2015. "Beyond Autochthony Discourses: Sherbro Identity and the (Re-) Construction of social and national cohesion in Sierra Leone.” PhD Diss., Martin-Luther University Halle-Wittenberg.

- 2017. "Interpreting Conflict and Integration through the Reciprocity Lens: Mobility and Settlement in a Historical Perspective on the Sierra Leonean Coast." Social Identities 23 (4): 413-29.

Mouser, Bruce. 1975. "Landlords-Strangers: A Process of Accommodation and Assimilation." The International Journal of African Historical Studies 8 (3): 425-40.

Murphy, William, and Caroline Bledsoe. 1987. "Kinship and Territory in the History of a Kpelle Chiefdom (Liberia)." In The African Frontier: The Reproduction of Traditional African Societies, edited by Igor Kopytoff, 123-47. Bloomington: Indiana University Press.

Paulme, Denise. 1960. "La societe Kissi: son organisation politique." Cahier d'etudes africaines 1-2: 73-85.

Rodney, Walter. 1980. A History of the Upper Guinea Coast, 1545-1800. New York: Monthly Review Press.

Shadle, Brett. 2018. "Refugees in African History." In A Companion to African History, edited by William H. Worger, Charles Ambler, and Nwando Achebe, 247-64. Medford: John Wiley and Sons.

Straus, Scott. 2011. "It's sheer horror here': Patterns of violence during the first four months of Côte d'Ivoire's post-electoral crisis." African Affairs 110 (440): 481-89.

Trajano Filho, Wilson. 2010. "The Creole Idea of Nation And Its Predicaments: The Case Of Guinea-Bissau." In The Powerful Presence of the Past: Integration and Conflict along the Upper Guinea Coast, edited by Jacqueline Knörr and Wilson Trajano Filho, 155-83. Leiden: Brill.

UNHCR. 2012. The 2011 Statistical Yearbook. Geneva: United Nations High Commission on Refugees.

Zetter, Roger. 1991. "Labeling Refugees: Forming and Transforming a Bureaucratic Identity.” Journal of Refugee Studies 4 (1): 39-62. 


\section{Notes}

1. For an in-depth analysis of the crisis in Ivory Coast, see McGovern 2011, MarshalFratani 2006.

2. The volume on the margins of the state, edited by Veena Das and Deborah Poole (2004), explores the way the state manifests itself in marginal places. Of particular interest in this regard are the chapters by Deborah Poole, Janet Roitman, and Jeganathan.

3. For instance, among the Loma (Beavogui 1991), the Temne (Dorjahn 1960), Gola (d'Azevedo 1959), Kissi (Paulme 1960), Kpelle (Bellman 1984; Fulton 1972), Sherbro (Ménard 2015, 2017) and Mende (Little 1965, 1966) ethnic groups.

4. i.e. a plot of land where peppers and other spices are grown. While rice is grown for household consumption, pepper is grown for sale on the market. For most people it is an "achievable" cash crop, unlike, e.g., kola. 